\title{
Peningkatan Kinerja Tenaga Kerja Bagian Sortasi Dan Grading Kulit Kayu Manis (C. Burmanii) Pada Cv. Rasdi \& Co Berdasarkan Faktor-Faktor Yang Berpengaruh
}

\author{
Improvement Of Working Performance In Sorting And Grading Of Cinnamon Skin \\ (C. Burmanii) In Rasdi Factory And Coorperation Based On Influencing Factors
}

\author{
Andri Syaputra \\ Program Studi Teknik Pendingin dan Tata Udara, Politeknik Tanjungbalai \\ Jl. Sei Raja Kecamatan Sei Tualang Raso Kota Tanjungbalai, Indonesia \\ Email : andrisyaputra98@gmail.com
}

\begin{abstract}
Labour productivity is also greatly influenced by working procedures, the skills of workers, machine design and production equipment, as well as working environment. In this research, doing the identification of factors affecting the workers in sorting and grading of cinnamon skin department. The five factors are used as independent variables were the work motivation $\left(X_{1}\right)$, work environment $\left(X_{2}\right)$, salary $\left(X_{3}\right)$, age $\left(X_{4}\right)$ and workload $\left(X_{5}\right)$ that are correlated with one dependent variable which is the performance $(Y)$. The Research conducted at Rasdi Fo \& Co Jl. Adinegoro No. 38. 25172 Padang Lalang Simpang West Sumatra. Sampling extraction method used in this study was stratified random sampling method. The Respondents were $\geq 25 \%$ from 70 production employees of Rasdi Fo \& Co. and the characteristic features are based on years of service, so the method that would be used was to look at the curriculum vitae of employees and then grouped based on the length of working as the representative of the entire population. The measurement results obtained, the results of the maximum temperature was $38,44^{\circ} \mathrm{C}$ and a minimum temperature was $29.33^{\circ} \mathrm{C}$ and this did not meet the standards set. The results of a maximum humidity was $91.3 \%$ and minimum humidity was $59,2 \%$ and also did not meet the standards set. The highest noise level was 78,4 $d B A$ and at the lowest measurement was 48,8 $d B A$ and was classified as normal without ear protection (1405/MENKES/SK/XI/ 2002).
\end{abstract}

Keywords: labour productivity, sorting and grading, cinnamon, power function.

\section{A. PENDAHULUAN}

Kontribusi subsektor perkebunan terhadap perekonomian nasional pada tahun 2018 mencapai $\mathrm{Rp} 1005$ triliun (Badan Pusat Statistik). Peran perkebunan tersebut cenderung mengalami peningkatan dari tahun ke tahun dalam memperkokoh pembangunan nasional.

Beberapa faktor pada sistem produksi terutama tenaga kerja perlu diperhatikan karena akan sangat berpengaruh terhadap usaha peningkatan produktivitas perusahaan. Jumlah tenaga kerja yang dimiliki suatu industri pada masa sekarang sangat mempengaruhi produktivitas kerja masa sekarang dan perencanaan kebutuhan tenaga kerja dapat mempengaruhi produktivitas kerja pada masa yang akan datang.

Produktivitas tenaga kerja juga sangat dipengaruhi oleh tata cara kerja, keterampilan pekerja, perancangan mesin dan peralatan produksi, serta kondisi lingkungan kerja. Semakin tinggi jumlah produk yang dihasilkan dengan jumlah tenaga kerja yang optimal serta perhatian penuh terhadap faktor-faktor yang berpengaruh lainnya maka diharapkan akan tercapai peningkatan produktivitas kerja sehingga mendatangkan keuntungan bagi perusahaan. Peningkatan produktivitas kerja merupakan salah satu tolak ukur keberhasilan pemanfaatan sumber daya manusia yang tersedia.

Produktivitas/Kinerja dari tenaga kerja diukur dari hasil atau pencapaian akhir yang diukur dengan tingkat keberhasilan yang diperoleh selama masa kerja. Kinerja menghasilkan keuntungan bagi semua pihak yang berkepentingan dalam ruang lingkup atau wilayah. Keberhasilan kinerja perusahaan tergantung pada kinerja tenaga kerja di masing-masing bagian atau elemen 
perusahaan. Menurut Heidjrachman dan Husnan mengemukakan beberapa faktor mengenai kebutuhan dan keinginan pegawai, yaitu gaji yang baik, pekerjaan yang aman, rekan sekerja yang kompak, penghargaan terhadap pekerjaan, pekerjaan yang berarti, kesempatan untuk maju, pimpinan yang adil dan bijaksana, pengarahan dan perintah yang wajar, dan organisasi atau tempat kerja yang dihargai oleh masyarakat.

Identifikasi faktor yang berpengaruh terhadap tenaga kerja bagian sortasi dan grading disebabkan oleh adanya masalah yang terdapat pada bagian sortasi dan grading itu sendiri. Masalah yang dihadapi oleh tenaga kerja adalah sebagian besar proses pelaksanaan sortasi dan grading membutuhkan pikiran, kemampuan serta fokus dalam menyelesaikan pekerjaan. Apabila terjadi kesalahan, akan mengakibatkan pekerja harus mengulang kembali proses kerja. Banyak hal yang harus dilakukan perusahaan untuk perbaikan dan peningkatan kinerja. Manfaat lain yang dapat diperoleh adalah mengetahui kondisi yang dialami tenaga kerja sehingga mampu mengambil keputusan dalam upaya meningkatkan dan mendorong efisiensi produksi dan tenaga kerja. Adapaun 5 faktor yang dijadikan sebagai variabel bebas adalah Motivasi, Lingkungan Kerja, Gaji, Usia, dan Beban kerja yang dihubungkan dengan satu variabel terikat yaitu produktivitas/Kinerja.

Studi kasus yang peneliti gunakan sebagai parameter adalah $\mathrm{CV}$. Rasdi \& Co, yang merupakan CV atau Perusahaan yang bergerak khusus dibidang Ekspor tanaman Rempah. Salah satunya adalah tanaman kayu manis atau Cassiavera yang juga menjadi komoditi andalan Sumatera Barat, dimana CV. Rasdi \& Co mampu mengekspor sebanyak 100 ton/bulan atau 1200 ton/tahun.

Pengolahan Kulit kayu manis dilakukan dengan cara manual dan mekanis. Untuk proses mekanis dilakukan setelah kulit kayu manis disortasi dari kualitas asalan dan dilanjutkan dengan menggrading kulit kayu manis berdasarkan kualifikasi kualitas yang telah ditetapkan untuk dilakukan pemotongan sesuai permintaan Ekspor. Adapun klasifikasi grading yang digunakan CV. Rasdi dan Co adalah KAA long stick, KAA per 5 dan $8 \mathrm{~cm}, \mathrm{KA}, \mathrm{KB}$, dan KC. Jadi berdasarkan itu semua, CV. Rasdi dan Co menggunakan tenaga kerja dalam 2 kelompok yaitu harian dan borongan. Harian mereka di gaji berdasarkan kuantitas yang di dapat. Bedanya dengan karyawan borongan mereka mensortir kulit kayu manis asalan dan setelah terkelompok menjadi KAA, $\mathrm{KA}, \mathrm{KB}, \mathrm{KC}$ baru dikerjakan oleh tenaga harian untuk proses grading. Kapasitas kerja rata-rata tenaga harian dan borongan adalah $325-340 \mathrm{~kg} / \mathrm{hari}$. Kondisi yang seperti ini masih bisa untuk ditingkatkan lagi, untuk itu kita disini akan menganalisa lebih lanjut agar dapat memaksimalkan produktivitas/kinerja dengan sumber daya manusia yang ada.

Jadi berdasarkan latar belakang permasalahan tersebut, maka dengan ini saya sebagai penulis akan mengangkat penelitian dengan judul "Peningkatan Kinerja Tenaga Kerja Bagian Sortasi dan Grading Kulit Kayu Manis (C. burmanii) Pada CV. Rasdi \& Co Berdasarkan FaktorFaktor yang Berpengaruh".

Penelitian ini bertujuan untuk mengetahui faktor-faktor yang paling berpengaruh terhadap tenaga kerja bagian sortasi dan grading kulit kayu manis dengan menggunakan uji f, uji t dan analisis menggunakan persamaan power function.

\section{B. METODOLOGI}

Penelitian dilaksanakan di CV. Rasdi \& Co Jl. Adinegoro No. 38 Simpang Lalang Padang 25172 Sumatera Barat. Adapun tempat pelaksanaan penelitiannya adalah pada bagian Gudang CV. Rasdi \& Co, selain sebagai tempat pengaturan barang datang, penyusunan, penimbangan, serta tempat penjemuran produk, tempat ini juga digunakan sebagai aktivitas karyawan untuk melakukan kegiatan produksi. Salah satunya adalah kegiatan sortasi dan grading kulit kayu manis. Sortasi dilakukan oleh karyawan borongan dan grading dilakukan oleh karyawan harian. Adapun alat-alat yang digunakan dalam penelitian ini adalah sebagai berikut:

(1) Sound Level Meter (SLM) yang digunakan untuk menagkap tingkat kebisingan yang tercipta. (2) Lux Meter 
atau Light Meter yang digunakan untuk mengukur intensitas cahaya. (3) Thermohygrometer digunakan untuk pengukuran suhu dan kelembaban udara. (4) Program SPSS sebagai Software yang digunakan untuk pengolahan data penelitian.

\section{Kerangka Pemikiran}

Kerangka pemikiran dalam penelitian ini adalah tenaga kerja sortasi dan grading kulit kayu manis CV Rasdi \& Co. yang dipengaruhi oleh beberapa faktor diantaranya motivasi kerja, lingkungan kerja, gaji, usia dan beban kerja. Variabel tersebut sebagai variabel bebas/independen dan bersama-sama dengan variabel terikat/dependen yaitu kinerja, kemudian diproses dengan software SPSS untuk mendapatkan signifikansinya dan dilanjutkan dengan analisis power function $\mathrm{Y}=10^{\mathrm{a} 0^{\prime}} \times \mathrm{X}_{1^{\mathrm{a}}} \mathrm{a}^{\prime} \times$

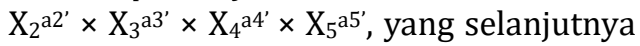
akan dijadikan sebagai acuan untuk merencanakan ide-ide baru bagi perusahaan dalam meningkatkan produktivitas/kinerja tenaga kerja sortasi dan grading kulit kayu manis. Untuk lebih jelasnya dapat dilihat pada Gambar 1.

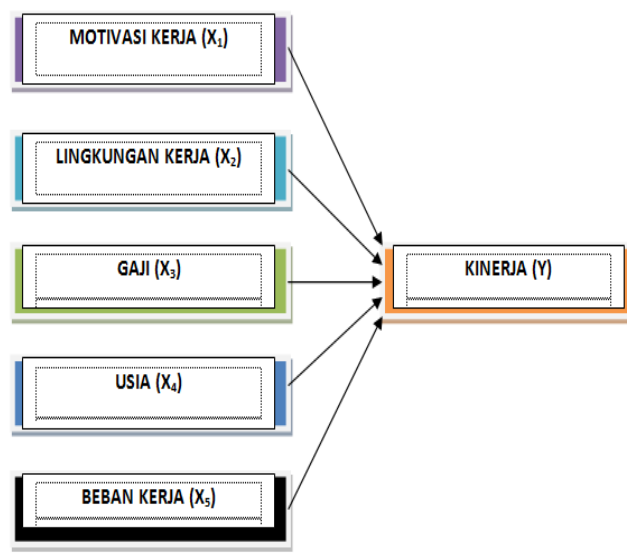

Gambar 1. Kerangka Pemikiran teoritis

\section{Metode Pengambilan Sampel}

Populasi adalah jumlah dari keseluruhan obyek penelitian (Djarwanto dan Subagyo, 1996). Dalam penelitian ini yang menjadi populasi adalah keseluruhan karyawan produksi yaitu sebanyak 70 orang.

Sampel adalah sebagian dari jumlah populasi yang karakteristiknya akan diteliti serta dianggap bisa mewakili keseluruhan dari jumlah populasi (Djarwanto dan Subagyo, 1996). Penentuan jumlah sampel yang dijadikan sebagai responden dalam penelitian ini adalah $\geq 25 \%$ dari populasi yang ada (Arikunto, 2002).

Metode Pengambilan Sampel, adapun teknik pengambilan sampel yang akan digunakan dalam penelitian ini adalah metode stratified random sampling, dengan pengertian bahwa populasi dalam penelitian ini bersifat heterogen, dengan langkah mengelompokkan populasi menjadi sub populasi berdasarkan pada karakteristik tertentu, sehingga pada setiap sub populasinya mempunyai anggota sampel yang homogen. Kemudian dari setiap sub populasi diambil secara acak untuk setiap anggota sampelnya sesuai dengan ciri-ciri karakteristik sampelnya dan untuk penelitian ini, responden yang digunakan adalah $\geq 25 \%$ dari 70 orang karyawan produksi CV Rasdi \& Co. dan ciri karakteristik adalah berdasarkan lama bekerja, jadi metode yang akan digunakan adalah dengan melihat data riwayat kerja karyawan dan kemudian dikelompokkan berdasarkan masa kerjanya sebagai perwakilkan dari seluruh populasi.

\section{Identifikasi dan Operasional Variabel}

Variabel penelitian terdiri dari satu variabel dependen yaitu kinerja/produktivitas kerja $(Y)$ dan variabel independen yaitu: motivasi $\left(X_{1}\right)$, lingkungan kerja $\left(X_{2}\right)$, gaji $\left(X_{3}\right)$, Usia $\left(X_{4}\right)$, dan beban kerja $\left(X_{5}\right)$.

Pengukuran variabel yang digunakan dalam penelitian ini adalah dengan menggunakan skala Likert. Menurut Sugiyono (2005), Skala Likert digunakan untuk mengukur sikap, pendapat, dan persepsi seseorang atau sekelompok orang tentang fenomena sosial. Dalam penelitian fenomena sosial ini telah ditetapkan secara spesifik oleh peneliti, yang selanjutnya disebut sebagai variabel penelitian. Jawaban setiap item instrumen yang menggunakan skala Likert mempunyai gradasi dari sangat positif sampai sangat negatif, yang dapat berupa kata-kata antara lain:

$$
\begin{array}{ll}
\text { SS } & =\text { Sangat Setuju } \\
\text { S } & =\text { Setuju } \\
\text { KS } & =\text { Kurang Setuju } \\
\text { TS } & =\text { Tidak Setuju }
\end{array}
$$


STS $=$ Sangat Tidak Setuju

\section{Teknik Analisis Data}

\section{Uji Statistik (Goodness of Fit)}

Setelah model bebas dari pengujian asumsi klasik, dilanjutkan dengan justifikasi statistik. Justifikasi statistik merupakan uji giving goodness of fit model yang menyangkut ketepatan fungsi regresi sampel dalam menaksir nilai aktual dengan melihat dari Goodness of Fitnya. Secara statistik, setidaknya ini dapat diukur dari nilai koefisien determinasi, nilai statistik $F$ dan nilai statistik t (Imam Ghozali, 2005).

\section{Koefisien Determinasi}

\begin{abstract}
Koefisien determinasi $\left(\mathrm{R}^{2}\right)$ pada intinya mengukur seberapa jauh kemampuan model dalam menerangkan variasi variabel terikat (dependen). Nilai koefisien determinasi adalah antara nol dan satu. Nilai $\mathrm{R}^{2}$ yang kecil berarti kemampuan variabel independen dalam menjelaskan variasi variabel dependen amat terbatas. Nilai yang mendekati satu berarti variabel-variabel independen memberikan hampir semua informasi yang dibutuhkan untuk memprediksi variabel dependen.
\end{abstract}

\section{Uji F}

$\begin{array}{cc}\text { Digunakan untuk menguji apakah } \\ \text { secara } & \text { bersama-sama variabel }\end{array}$ independen (motivasi kerja, lingkungan kerja, gaji, usia, dan beban kerja) secara signifikan dapat menjelaskan variabel dependen (kinerja) dalam fungsi kuadrat (power function).

Uji t

Digunakan mengidenfitikasi apakah masing-masing variabel bebas/ independen (motivasi kerja, lingkungan kerja, gaji, usia, dan beban kerja) mempunyai pengaruh yang signifikan terhadap variabel terikat/dependen (kinerja).

\section{Utilitas Pangkat atau Fungsi Pangkat (Power Function)}

Digunakan untuk mengetahui besarnya pengaruh dari masing-masing variabel independen (motivasi kerja, lingkungan kerja, gaji, usia, dan beban kerja) terhadap variabel dependen (kinerja) dalam penelitian.

Persamaan yang digunakan adalah (Santosa, 2005) :

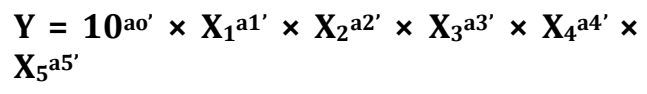

Lingkungan Kerja Sebagai Faktor yang Mempengaruhi Kinerja Karyawan

Adapun lingkungan kerja sebagai faktor yang mempengaruhi kinerja karyawan meliputi :

\section{Suhu Udara dan Kelembaban}

Suhu udara adalah besaran yang menyatakan derajat panas dingin suatu benda dan alat yang digunakan untuk mengukur suhu adalah thermometer, sedangkan suhu dan kelembaban bersama-sama diukur dengan thermohygrometer. Keputusan Menteri Kesehatan Republik Indonesia Nomor 1405/MENKES/SK/XI/2002 Tentang Persyaratan Kesehatan Lingkungan Kerja Perkantoran Dan Industri standar Suhu adalah Suhu $18^{\circ} \mathrm{C}-28^{\circ} \mathrm{C}$.

Kelembaban udara (humidity gauge) adalah jumlah uap air di udara (atmosfer). Kelembaban adalah konsentrasi uap air diudara. Kelembaban udara adalah tingkat kebasahan udara karena dalam udara air selalu terkandung dalam bentuk uap air. Angka konsentasi ini dapat diekspresikan dalam kelembaban absolut, kelembaban spesifik atau kelembaban relatif. Alat yang digunakan untuk mengukur kelembaban disebut dengan Higrometer, sedangkan suhu dan kelembaban bersama-sama diukur dengan thermohygrometer. Persyaratan Keputusan Menteri Kesehatan Republik Indonesia Nomor 1405/MENKES/SK/XI/2002 Tentang Persyaratan Kesehatan Lingkungan Kerja Perkantoran Dan Industri standar Kelembaban adalah $40 \%$ - $60 \%$.

\section{Pencahayaan}

Pencahayaan adalah jumlah penyinaran pada suatu bidang kerjayang diperlukan untuk melaksanakan kegiatan secara efektif. Persyaratan Keputusan Menteri Kesehatan Republik Indonesia Nomor

1405/MENKES/SK/XI/2002 Tentang

40 Persyaratan Kesehatan Lingkungan Kerja 
Perkantoran Dan Industri standart intensitas cahaya di ruang kerja minimal 100 lux. Prinsip penerangan yang baik adalah jumlah dan intensitas penerangan yang diperlukan hendaknya disesuaikan dengan jenis pekerjaan, daya lihat seseorang dan lingkungannya.

Alat yang digunakan untuk mengukur intensitas cahaya adalah Lux meter. Untuk mengukur pencahayaan digunakan teknik pengukuran Local Lighting.

\section{Kebisingan}

Kebisingan adalah terjadinya bunyi yang tidak dikehendaki sehingga mengganggu atau membahayakan kesehatan. Dengan kata lain tiap bunyi yang tidak diinginkan oleh penerima dianggap sebagai bising. Jadi pembicaraan atau musik dianggap sebagai bising bila mereka tidak diinginkan. Seseorang cenderung mengabaikan bising bila bising itu secara wajar menyertai pekerjaan, seperti mesin ketik atau mesin di pabrik. Sumber bising dapat dikelompokkan menjadi dua, yaitu: (1) bising interior bisa dari alat-alat seperti mobil, motor, kipas angin, AC, televisi, radio, penghisap debu, mesin bor, dan (2) outdoor, seperti bunyi air hujan, angin, air mengalir. Bising berfrekuensi tinggi lebih mengganggu dari pada bising frekuensi rendah. Secara umum bising bias menghasilkan gangguan yang jauh lebih besar pada malam hari dari pada siang hari. Menurut Keputusan Menteri Kesehatan Republik Indonesia

Nomor1405/MENKES/SK/XI/2002

Tentang Persyaratan Kesehatan Lingkungan Kerja Perkantoran dan Industri standar tingkat kebisingan di ruang kerja tanpa pelindung maksimal 85 dBA.

Pengukuran kebisingan dilakukan dengan menggunakan Sound Level Meter. Prinsip kerja alat ini adalah dengan mengukur tingkat tekanan bunyi. Tekanan bunyi adalah penyimpangan dalam tekanan atmosfer yang disebabkan oleh getaran partikel udara karena adanya gelombang yang dinyatakan sebagai amplitudo dari fluktuasi tekanan.

\section{HASIL DAN PEMBAHASAN}

Deskripsi Kegiatan Sortasi dan Grading Kulit Kayu Manis CV Rasdi \& Co
Lingkungan kerja karyawan sortasi dan grading kulit kayu manis tidak jauh berbeda dengan pinang, hanya saja mereka lebih banyak indoor dari pada outdoor dalam melakukan proses sortir dan garding kulit kayu manis. Barang yang masuk ke CV. Rasdi \& Co adalah kulit kayu manis asalan dimana nanti akan di grading atau dikelompokkan menjadi $\mathrm{KA}, \mathrm{KB}, \mathrm{KABC}$, dan KBBC.

Tenaga kerja sortasi dan grading untuk kulit kayu manis terbagi dua yakni borongan dan harian. Borongan mereka di gaji berdasarkan kuantitas yang di dapat. Bedanya dengan karyawan harian mereka mensortir kulit kayu manis asalan dan setelah di grading/terkelompok menjadi KA, KB, KABC, dan KBBC baru dikerjakan oleh karyawan harian.

Upah borongan tenaga kerja kulit manis $\mathrm{KA} / \mathrm{KB}=\mathrm{Rp} 175$ per kilo, rata-rata mereka bisa menyortir $325 \mathrm{~kg} /$ hari. Perlengkapan kerja yang digunakan oleh tenaga kerja borongan kulit kayu manis adalah topi, pisau cutter, masker, sarung tangan. Peralatan mesin potong, jika ada permintaan potong serta mesin gerinda untuk membuat cassia vera broken clean yang dikerjakan oleh tenaga kerja harian.

Oleh karena gambaran diatas mengenai deskripsi tempat masih mengambang dan kurang jelas, maka dari itu kita akan memberikan gambaran yang lebih jelas mengenai kondisi tempat kerja di CV Rasdi \& Co. Berikut merupakan denah CV Rasdi \& Co. yang terjabar pada Gambar 2.

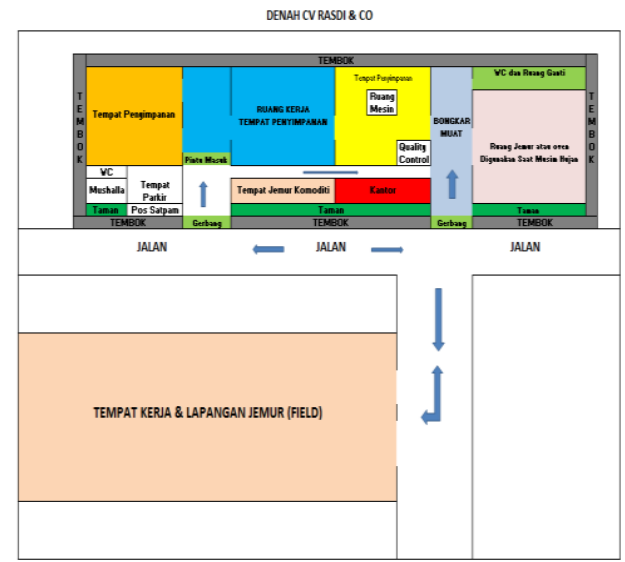

Gambar 2. Denah CV. Rasdi \& Co

Ketepatan fungsi regresi dalam menaksir nilai aktual dapat diukur dari Goodness of Fitnya. Secara statistik, setidaknya ini dapat diukur dari nilai 
koefisien determinasi, nilai statistik F dan nilai statistik $\mathrm{t}$.

\section{Uji Koefisien Determinasi $\left(\mathbf{R}^{2}\right)$}

Nilai koefisien determinasi $\left(\mathrm{R}^{2}\right)$ ini mencerminkan seberapa besar variasi dari variabel terikat $Y$ dapat diterangkan oleh variabel bebas $\mathrm{X}$, atau dengan kata lain seberapa besar $\mathrm{X}$ memberikan kontribusi terhadap Y. Koefisien determinasi digunakan untuk menguji goodness-fit dari model regresi yang dapat lihat dari nilai $\mathrm{R}$ Square. Nilai $\mathrm{R}^{2}$ dapat dilihat pada Tabel 1 berikut ini:

Tabel 1. Hasil Uji Regresi (Koefisien Determinasi)

\begin{tabular}{l|r|r|r|r|}
\hline \multicolumn{5}{|c|}{ Model Summary $^{\mathrm{b}}$} \\
\hline Model & $\mathrm{R}$ & R Square & $\begin{array}{c}\text { Adjusted R } \\
\text { Square }\end{array}$ & $\begin{array}{c}\text { Std. Error of the } \\
\text { Estimate }\end{array}$ \\
\hline 1 &, $859^{\mathrm{a}}$ &, 738 &, 644 &, 01320 \\
\hline
\end{tabular}

Keterangan : a. Predictors: (Constant), Beban_Kerja, Motivasi_Kerja, Usia, Lingkungan_Kerja, Gaji, b. Dependent Variabel: Kinerja

Untuk mengetahui tingkat kinerja karyawan sortasi dan grading CV. Rasdi \& CO yang dipengaruhi oleh beberapa faktor antara lain yaitu (motivasi kerja, lingkungan kerja, gaji, usia dan beban kerja) dapat dilihat melalui besarnya koefisien determinasi. Pada Tabel 1 nilai $\mathrm{R}$ Square adalah 0,738. Hal ini dapat diartikan bahwa sebesar $73.8 \%$ dari kinerja tenaga kerja sortasi dan grading CV. Rasdi \& Co dapat dijelaskan oleh motivasi kerja $\left(\mathrm{X}_{1}\right)$, lingkungan kerja $\left(\mathrm{X}_{2}\right)$, gaji $\left(X_{3}\right)$, usia $\left(X_{4}\right)$ dan beban kerja $\left(X_{5}\right)$, sedangkan sisanya $26,2 \%$ diterangkan oleh faktor lain yang tidak diteliti.

\section{Uji Simultan (Uji F)}

Uji-F digunakan untuk membuktikan apakah variabel bebas (motivasi kerja, lingkungan kerja, gaji, usia dan beban kerja) secara bersamasama (simultan) mempunyai pengaruh yang signifikan baik positif maupun negatif terhadap variabel terikatnya (kinerja). Hasil uji $\mathrm{f}$ pada penelitian ini dapat 2ilihat pada tabel 2 berikut ini:
Tabel 2. Hasil Uji F

\begin{tabular}{|c|c|c|c|c|c|c|}
\hline \multicolumn{7}{|c|}{ ANOVA } \\
\hline \multicolumn{2}{|c|}{ Model } & $\begin{array}{l}\text { Sum of } \\
\text { Squares }\end{array}$ & & $\begin{array}{l}\text { Mean } \\
\text { Square }\end{array}$ & & Sig. \\
\hline \multirow[t]{3}{*}{1} & Regression & .007 & 5 & .001 & 7,876 & $.001^{\mathrm{a}}$ \\
\hline & Residual & .002 & 14 & .000 & & \\
\hline & Total & 000 & 19 & & & \\
\hline
\end{tabular}

Keterangan : a. Predictors: (Constant), Beban_Kerja, Motivasi_Kerja, Usia, Lingkungan_Kerja, Gaji, b. Dependent Variabel: Kinerja

Dari hasil uji F pada penelitian ini didapatkan nilai $\mathrm{F}$ hitung sebesar 7,876 dengan angka signifikansi sebesar 0,001. Dengan tingkat signifikansi $95 \% \quad(\alpha$ $=0,05)$. Berdasarkan hasil uji $\mathrm{F}$ di atas, maka $\mathrm{H}_{1}$ diterima. Hal ini berarti bahwa motivasi kerja, lingkungan kerja, gaji, usia dan beban kerja secara bersama-sama berpengaruh signifikan terhadap kinerja karyawan sortasi dan grading.

\section{Uji Signifikan Parameter Parsial (Uji t)}

Pada uji statistik secara parsial dengan nilai t kritis (critical value) pada $\mathrm{df}=(\mathrm{n}-\mathrm{k})$, dimana $\mathrm{n}$ adalah jumlah sampel dan $\mathrm{k}$ adalah jumlah variable bebas termasuk konstanta. Berikut ini adalah hasil uji t pada penelitian ini dan dapat dilihat di Tabel 3.

Tabel 3. Hasil Uji t

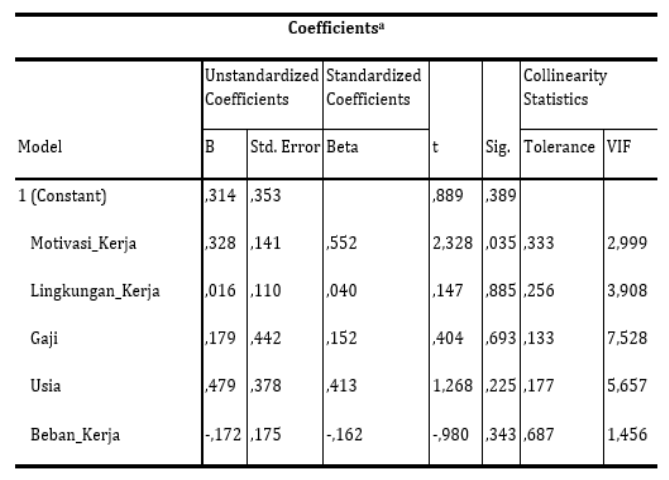

Keterangan : a. Dependent Variabel: Kinerja

Dari hasil uji t. pada penelitian ini untuk nilai variabel $\mathrm{X}_{2}, \mathrm{X}_{3}, \mathrm{X}_{4}$ dan $\mathrm{X}_{5}$ t.hitung < t.tabel sebesar 2,101 dan angka signifikasi $>0,05$. Hal ini berarti $\mathrm{H}_{0}$ diterima. Hanya pada variabel $\mathrm{X}_{1}$ yang sesuai dengan aturan regresi berganda. Pada variabel $\mathrm{X}_{1}$ nilai t.hitung besar dari 2,101 dan angka signifikansi < 0,05. Ini berarti $\mathrm{H}_{1}$ diterima. Variabel Motivasi 42 Kerja $\left(X_{1}\right)$ secara parsial berpengaruh terhadap kinerja karyawan sortasi dan grading. 


\section{Utilitas Pangkat atau Fungsi Pangkat (Power Function)}

Berdasarkan perhitungan yang dilakukan melalui statistik dengan menggunakan program SPSS, maka diperoleh hasil pada tabel 4 berikut :

Tabel 4. Hasil SPSS untuk Fungsi Pangkat (Power Function)

\begin{tabular}{|c|c|c|c|c|c|c|c|}
\hline \multirow[b]{3}{*}{ Model } & \multicolumn{5}{|c|}{ Coefficients $^{\mathrm{a}}$} & & \\
\hline & \multicolumn{2}{|c|}{$\begin{array}{l}\text { Unstandardized } \\
\text { Coefficients }\end{array}$} & \multirow{2}{*}{\begin{tabular}{|l|}
$\begin{array}{l}\text { Standardized } \\
\text { Coefficients }\end{array}$ \\
Beta
\end{tabular}} & \multirow[b]{2}{*}{ t } & \multirow[b]{2}{*}{ Sig. } & \multicolumn{2}{|c|}{$\begin{array}{l}\text { Collinearity } \\
\text { Statistics }\end{array}$} \\
\hline & B & Std. Error & & & & Tolerance & VIF \\
\hline 1 (Constant) & .314 & .353 & & 889 & .389 & & \\
\hline $\begin{array}{l}\text { Motivasi } \\
\text { Kerja }\end{array}$ & .328 & ,141 &, 552 & 2,328 & .035 & .333 & 2,999 \\
\hline $\begin{array}{l}\text { Lingkungan } \\
\text { Kerja }\end{array}$ & .016 &, 110 &, 040 & ,147 & 885 & .256 & 3,908 \\
\hline Gaii & 179 & .442 &, 152 & .404 & .693 & .133 & 7,528 \\
\hline Usia & 479 & .378 & 413 & 1,268 & .225 & 177 & 5,657 \\
\hline Beban Kerja &,- 172 &, 175 &,- 162 & -980 &, 343 & .687 & 1,456 \\
\hline
\end{tabular}

Keterangan : a. Dependent Variabel: Kinerja

Berdasarkan output SPSS diatas, maka diperoleh fungsi pangkat sebagai berikut :

$\mathrm{Y}=2,06 \times \mathrm{X}_{1}{ }^{0,328} \times \mathrm{X}_{2} 0.016 \times \mathrm{X}_{3}^{0,179} \times \mathrm{X}_{4}^{0,479}$ $\times \mathrm{X}_{5}-0,172$

Model tersebut menunjukkan bahwa :

1. Konstanta $=2,06$

Jika variabel motivasi kerja, lingkungan kerja, gaji, usia dan beban kerja di asumsikan 0 maka kinerja karyawan akan meningkat sebesar 2,06.

2. Koefisien Motivasi Kerja $\mathrm{X}_{1} \mathrm{a1}^{\prime}=\mathrm{X}_{1} 0,328$ Nilai koefisien motivasi kerja sebesar 0,328 dalam fungsi pangkat, menyatakan bahwa setiap terjadi kenaikan 1 skor untuk motivasi kerja akan diikuti terjadi kenaikan kinerja karyawan sebesar $\left(\wedge^{\wedge 0,328}\right)$ dengan asumsi bahwa variabel bebas yang lain dari fungsi pangkat adalah tetap

3. Koefisien Lingkungan Kerja $\mathrm{X}_{2}=\mathrm{X}_{2}{ }^{0,016}$ Nilai koefisien Lingkungan Kerja menunjukkan angka sebesar 0,016 dalam fungsi pangkat, menyatakan bahwa apabila terjadi kenaikan 1 skor untuk lingkungan kerja akan di ikuti dengan terjadi kenaikan kinerja karyawan sebesar $\left({ }^{\wedge} 0,016\right)$ dengan asumsi bahwa variabel bebas yang lain dari fungsi pangkat adalah tetap.

4. Koefisisen Gaji $\mathrm{X}_{3}=\mathrm{X}_{3}{ }^{0,179}$

Nilai koefisien Gaji menunjukkan angka sebesar 0,179 dalam fungsi pangkat, menyatakan bahwa apabila terjadi kenaikan 1 skor untuk Gaji akan di ikuti dengan terjadi kenaikan kinerja karyawan sebesar $\left(\wedge^{\wedge} 0,179\right)$ dengan asumsi bahwa variabel bebas yang lain dari fungsi pangkat adalah tetap.

5. Koefisien Usia $\mathrm{X}_{4}=\mathrm{X}_{4}{ }^{0,479}$

Nilai koefisien Usia menunjukkan angka sebesar 0,479 dalam fungsi pangkat, menyatakan bahwa apabila terjadi kenaikan 1 skor untuk Usia akan di ikuti dengan terjadi kenaikan kinerja karyawan sebesar $\left({ }^{\wedge} 0,479\right)$ dengan asumsi bahwa variabel bebas yang lain dari fungsi pangkat adalah tetap.

6. Koefisien Beban Kerja $\mathrm{X}_{5}=\mathrm{X}_{5}^{-0,172}$

Nilai koefisien Beban Kerja menunjukkan angka sebesar 0,172 dan bertanda negatif dalam fungsi pangkat, menyatakan bahwa terjadi hubungan yang berlawanan arah dengan kinerja karyawan. Hal ini mengandung arti bahwa setiap kenaikan 1 skor variabel (Y) akan turun sebesar $\quad(\wedge-0,172)$ dengan asumsi bahwa variabel bebas yang lain dari fungsi pangkat adalah tetap.

\section{Lingkungan Kerja Sebagai Faktor yang Mempengaruhi Kinerja Karyawan.}

\section{Pengukuran Suhu dan Kelembaban Udara}

Menurut Persyaratan Keputusan Menteri Kesehatan Republik Indonesia Nomor 1405/MENKES/SK/XI/2002 Tentang Persyaratan Kesehatan Lingkungan Kerja Perkantoran Dan Industri, standar suhu adalah $18{ }^{\circ} \mathrm{C}-28$ ${ }^{\circ} \mathrm{C}$. Berdasarkan hasil pengukuran yang didapatkan hasil suhu maksimal sebesar $38,44{ }^{\circ} \mathrm{C}$ dan suhu minimal sebesar 29,33 ${ }^{\circ} \mathrm{C}$. Hal ini menunjukkan suhu udara di dalam ruangan kerja sortasi dan grading kulit kayu manis telah melebihi standar yang telah ditentukan.

Sementara untuk kelembaban, menurut Persyaratan Keputusan Menteri Kesehatan Republik Indonesia Nomor1405/MENKES/SK/XI/2002

Tentang Persyaratan Kesehatan Lingkungan Kerja Perkantoran dan Industri, Standar kelembaban adalah 40 \% - 60 \%. Berdasarkan hasil pengukuran yang didapatkan hasil kelembaban 
maksimal sebesar 91,3 \% dan kelembaban minimal sebesar 59,2 \%. Hal ini menunjukkan kelembaban udara di dalam ruangan sortasi dan grading kulit kayu manis dominan mutlak tidak memenuhi standar yang telah ditentukan.

\section{Pengukuran Pencahayaan}

\begin{tabular}{lrr}
\multicolumn{2}{c}{ Keputusan Menteri } & Kesehatan \\
Republik Nomor & Indonesia & Nomor \\
1405/MENKES/SK/XI/2002 & Tentang
\end{tabular} Persyaratan Kesehatan Lingkungan Kerja Perkantoran Dan Industri, standar intensitas cahaya di ruang kerja minimal 100 lux. Berdasarkan pengukuran yang dilakukan, maka didapatkan hasil pada pengukuran intensitas cahaya tertinggi di dalam ruangan sortasi dan grading kulit manis adalah 28,2 $\times 10^{2}$ lux pada saat pengambilan hari kedua pukul $13.00 \mathrm{di}$ ulangan ke-2 dan pengukuran terendah sebesar 70 lux pada saat pengambilan hari pertama pukul 07.00 di ulangan ke-1. Hal ini disebabkan karena bertepatan di siang hari dan ditambah sinar matahari langsung mengenai tenaga kerja.

Maka, apabila dibandingkan dengan standar yang telah ditetapkan oleh Keputusan Menteri Kesehatan Republik Indonesia Nomor 1405/MENKES/SK/XI/2002 dapat dikatakan tingkat pencahayaan di dalam ruangan sortasi dan grading kulit kayu manis telah sesuai standar yang telah ditetapkan.

\section{Pengukuran Kebisingan}

Kebisingan adalah terjadinya bunyi yang tidak dikehendaki sehingga mengganggu atau membahayakan kesehatan. Manusia masih mampu mendengar bunyi dengan frekuensi antara 16-20.000 Hz, dan intensitas dengan nilai ambang batas (NAB) $85 \mathrm{~dB}$ (A) secara terus menerus. Intensitas lebih dari $85 \mathrm{~dB}$ dapat menimbulkan gangguan dan batas ini disebut critical level of intensity. Menurut Keputusan Menteri Kesehatan Republik Indonesia Nomor 1405/MENKES/SK/XI/2002 Tentang Persyaratan Kesehatan Lingkungan Kerja Perkantoran dan Industri, standar tingkat kebisingan di ruang kerja tanpa pelindung maksimal 85 dBA. Berdasarkan pengukuran yang telah dilakukan, tingkat kebisingan tertinggi $78,4 \mathrm{dBA}$ dan pada pengukuran terendah sebesar 48,8 dBA.
Hal tersebut menandakan bahwa tingkat kebisingan tersebut tergolong normal dan dapat dikategorikan sebagai zona aman tanpa pelindung, jadi dikarenakan tingkat kebisingan masih tergolong normal maka tidak akan menyebabkan gangguan kesehatan baik fisik (ketulian) maupun psikologis (stres akibat terlalu bising).

\section{Usulan/Rekomendasi Perbaikan Kinerja Tenaga Kerja Sortasi dan Grading.}

\section{Motivasi Kerja}

Secara simultan dan parsial motivasi kerja berpengaruh terhadap kinerja tenaga kerja sortasi dan grading kulit kayu manis, terutama secara parsial, karena memperoleh signifikan lebih kecil dari 0,05 sehingga $\mathrm{H}_{1}$ yang berbunyi "motivasi kerja berpengaruh terhadap kinerja tenaga kerja sortasi dan grading kulit kayu manis" diterima. Hal ini menunjukkan bahwa dengan adanya motivasi yang baik dalam bekerja akan memperoleh kinerja karyawan yang maksimal sedangkan dengan motivasi yang kurang akan menghasilkan kinerja karyawan yang rendah. Hal ini sesuai dengan teori Handoko (2001) yang menyatakan bahwa motivasi merupakan salah satu faktor yang dapat mempengaruhi kinerja karyawan. Terkait dengan pendapat tersebut, seseorang yang termotivasi untuk bekerja maka kinerja yang dihasilkan akan optimal.

Berdasarkan hasil penelitiaan ditemukan indikasi yang rendah pada variabel motivasi kerja pada indikator rasa aman dan kebutuhan sosial. Kondisi ini bisa dilihat dari jawaban responden dari kebutuhan rasa aman yaitu belum adanya jaminan masa depan yang lebih baik dari perusahaan dan jaminan akan keselamatan kerja oleh sebagian karyawan. Diharapkan dari kebutuhan rasa aman bisa diatasi seperti dengan adanya jaminan hari tua setelah masa kerja habis ataupun jaminan diikut sertakan dalam program jamsostek.

\section{Lingkungan Kerja}

Kontribusi Lingkungan kerja yang belum besar pengaruhnya terhadap kinerja tenaga kerja sortasi dan grading. Kondisi ini berdasarkan hasil pengukuran suhu dan kelembaban ruang kerja yang melebihi standar dan indikasi yang 
kurang memuaskan dari kuisioner terhadap failitas yang tersedia.

Jadi untuk masa yang akan datang, bagi perusahaan disarankan untuk lebih memperhatikan tempat bekerja karyawan, misalnya dengan menambah lubang ventilasi atau lubang angin sehingga suhu dan kelembaban tempat bekerja bisa disesuaikan dengan Keputusan Menteri Kesehatan Republik Indonesia Nomor 1405/MENKES/SK/ $\mathrm{XI} / 2002$ serta selalu melakukan evaluasi berkala terhadap fasilitas-fasiltas yang tersedia, sehingga jelas mana yang perlu ditambah atau dikurangi alhasil karyawan dapat bekerja aman, nyaman, dan optimal.

\section{Gaji}

Berdasarkan hasil analisis yang telah dilakukan, indikator gaji berpengaruh seara simultan terhadap kinerja karyawan. Hal ini berbanding lurus dengan kinerja yang dihasilkan. Usulan bagi perusahaan, sebaiknya lebih memperhatikan finansial karyawan, dengan memberikan bonus secara berkala untuk menutupi kekurangan gaji yang diterima karyawan. Sebagai catatan rata-rata kinerja karyawan perhari adalah $325 \mathrm{~kg}$ dengan upah per $\mathrm{kg} \mathrm{Rp} 175$,artinya setiap hari karyawan menerima Rp 56.875,- dan sebulan sekitar Rp 1.478.750,- dan itu masih dibawah UMR.

\section{Usia}

Dari hasil analisis yang dilakukan, indikator usia sangat berpengaruh secara simultan terhadap kinerja karyawan. Atinya usia berbanding lurus dengan kinerja karyawan. Diharapkan kepada perusahaan selalu mempertahankan bahkan menambah jumlah usia produktif yang bekerja, karena usia yang produktif dapat bekerja lebih optimal terhadap standar yang telah ditetapkan perusahaan.

\section{Beban Kerja}

Berdasarkan hasil analisis yang telah dilakukan, maka beban kerja berbanding terbalik dengan kinerja karyawan. Artinya kinerja bagus apabila beban kerja dikurangi. Akan tetapi, kemungkinan hal tersebut bisa di minimalisir. Ini ada kaitannya dengan faktor lingkungan kerja yang berhubungan dengan ketersediaan fasilitas dan Alat Pelindung Diri (APD), jadi sekali lagi diusulkan pada perusahaan untuk memaksimalkan fasiltitas bagi karyawannya agar memperoleh kinerja yang optimal.

\section{KESIMPULAN}

1. Dari hasil uji $\mathrm{F}$ yang dilakukan, variabel motivasi kerja, lingkungan kerja, gaji, usia dan beban kerja secara bersama-sama berpengaruh signifikan terhadap kinerja karyawan sortasi dan grading kulit kayu manis, ini dibuktikan dengan nilai $\mathrm{F}$ hitung sebesar 7,876 dengan angka signifikansi sebesar 0,001 dengan tingkat signifikansi $95 \%(\alpha=0,05)$ maka $\mathrm{H}_{1}$ diterima

2. Dari hasil analisis Uji-t yang telah dilakukan, variabel $\mathrm{X}_{2}, \mathrm{X}_{3}, \mathrm{X}_{4}$, dan $\mathrm{X}_{5}$ t.hitung < t.tabel sebesar 2,101 dan angka signifikasi $>0,05$, maka $\mathrm{H}_{0}$ diterima. Hanya pada variabel $\mathrm{X}_{1}$ yang sesuai dengan aturan regresi berganda. Pada variabel $\mathrm{X}_{1}$ nilai t.hitung besar dari 2,101 dan angka signifikansi $<0,05$, sehingga $\mathrm{H}_{1}$ diterima. Variabel Motivasi Kerja ( $\left.\mathrm{X}_{1}\right)$ secara parsial berpengaruh terhadap kinerja karyawan sortasi dan grading kulit kayu manis

3. Fungsi Pangkat (Power Function) yang dihasilkan adalah

$$
\begin{aligned}
& \mathrm{Y}=2,06 \times \mathrm{X}_{1} 0,328 \times \mathrm{X}_{2} 0.016 \times \mathrm{X}_{3}{ }^{0,179} \\
& \times \mathrm{X}_{4} 4^{0,479} \times \mathrm{X}_{5}^{-0,172}
\end{aligned}
$$

4. Berdasarkan hasil pengukuran yang didapatkan, hasil suhu maksimal sebesar $38,44{ }^{\circ} \mathrm{C}$ dan suhu minimal sebesar 29,33 ${ }^{\circ} \mathrm{C}$. Hal ini menunjukkan suhu udara di dalam ruangan kerja sortasi dan grading kulit kayu manis telah melebihi standar yang telah ditentukan dan pengukuran yang didapatkan, hasil kelembaban maksimal sebesar 91,3 $\%$ dan kelembaban minimal sebesar $59,2 \%$. Hal ini menunjukkan kelembaban udara di dalam ruangan sortasi dan grading kulit kayu manis dominan mutlak tidak memenuhi standar yang telah ditentukan.

5. Pencahayaan di dalam ruangan sortasi dan grading kulit manis telah sesuai standar yang telah ditetapkan, 
Andri Syaputra / Agrintech | Jurnal Teknologi Pangan dan Hasil Pertanian 3 (1) 2019,37-46

yakni minimal 100 lux

(1405/MENKES/SK/XI/2002) dan tingkat kebisingan tertinggi 78,4 dBA dan pada pengukuran terendah sebesar 48,8 dBA. Hal tersebut menandakan bahwa tingkat kebisingan tersebut tergolong normal dan dapat dikategorikan sebagai zona aman tanpa pelindung (1405/MENKES/SK/XI/2002).

\section{DAFTAR PUSTAKA}

Arikunto, S. 2002. Prosedur Penelitian : Suatu Pendekatan Praktek. Edisi Revisi V. Jakarta : PT Rineka Cipta.

Djarwanto dan S. Pangestu, 1996. Statistik Induktif, Edisi enam, Yogyakarta : BPFE
Ghozali, I. 2009. Aplikasi Analisis Multivariate dengan Program SPSS. Semarang: B-P UNDIP

Handoko, T.H. 2001. Manajemen Personalia dan Sumber Daya Manusia. Yogyakarta: BPFE Press.

Heidjrahman dan Hasan, S. 1992. Manajemen Personalia, Yogyakarta: BPFE.

Santosa, 2005. Aplikasi Visual Basic 6.0 dan Visual Studio.Net 2003 Dalam Bidang Teknik Petanian. Yogyakarta : Andi

Sugiyono, 2005. Statistika untuk Penelitian. Alfabeta, Bandung 